\title{
Valve-sparing aortic root surgery in children and adults with congenital heart disease
}

Edward Buratto, MBBS, PhD, ${ }^{\mathrm{a}, \mathrm{b}, \mathrm{c}}$ and Igor E. Konstantinov, MD, PhD, FRACS ${ }^{\mathrm{a}, \mathrm{b}, \mathrm{c}, \mathrm{d}}$

Aortic root surgery in patients with congenital heart disease was traditionally reserved for children with connective tissue disorders. ${ }^{1-3}$ In recent years, there has been an increasing number of patients, especially those with repaired conotruncal anomalies, who develop aneurysmal aortic root dilatation with or without concomitant aortic valve insufficiency. ${ }^{4,5}$ However, rupture and dissection of the aorta are exceedingly rare in childhood, ${ }^{6,7}$ and as such the precise criteria for aortic root surgery have not been defined. ${ }^{3,4}$ Although valve-sparing aortic root replacement has been the gold standard for decades, ${ }^{1-3}$ there is a newer approach combining replacement of the ascending aorta and external root stabilization, as well as a renewed interest in external support of the entire root, ${ }^{8-10}$ which have evolved from previously described aortic root wrapping. ${ }^{11}$ Of note, stabilization of the ascending aorta and entire aortic root can be performed without cardiopulmonary bypass, ${ }^{9,10}$ and if its effectiveness in root stabilization and reduction of aortic insufficiency is demonstrated, could further modify indications for aortic root surgery. The purpose of this focused review is to highlight key references on the current state of aortic root surgery in patients with congenital heart disease.

\section{INDICATIONS FOR SURGERY}

Aortic root surgery may be required because of progressive aortic regurgitation (AR) or prophylactically to prevent potential dissection and rupture of the aneurysmal aorta. The indications for aortic root surgery in children are elusive, derived from adult guidelines, ${ }^{12,13}$ and mainly focused on those with connective tissue disorders. ${ }^{2}$ The current guidelines are not data-driven or evidence-based, but rather derived from those developed for adults. ${ }^{14}$ In adults, to account for variation in patient size, aortic cross-sectional area has been be indexed to height (Svensson's index) to predict the risk of aortic

\footnotetext{
From the a Department of Cardiac Surgery, Royal Children's Hospital, Melbourne, Australia; 'bepartment of Paediatrics, University of Melbourne, Melbourne, Australia; 'Heart Research Group, Murdoch Children's Research Institute, Melbourne, Australia; and ${ }^{\mathrm{d}}$ Melbourne's Centre for Cardiovascular Genomics and Regenerative Medicine, Melbourne, Australia.

Received for publication June 25, 2020; revisions received Aug 4, 2020; accepted for publication Aug 11, 2020; available ahead of print Sept 28, 2020.

Address for reprints: Igor E. Konstantinov, MD, PhD, FRACS, Royal Children's Hospital, Flemington Rd, Parkville 3052, Australia (E-mail: igor.konstantinov@rch. org.au).

J Thorac Cardiovasc Surg 2021;162:955-62 0022-5223/\$36.00

Crown Copyright $(\subset) 2020$ Published by Elsevier Inc. on behalf of The American Association for Thoracic Surgery

https://doi.org/10.1016/j.jtcvs.2020.08.116
}

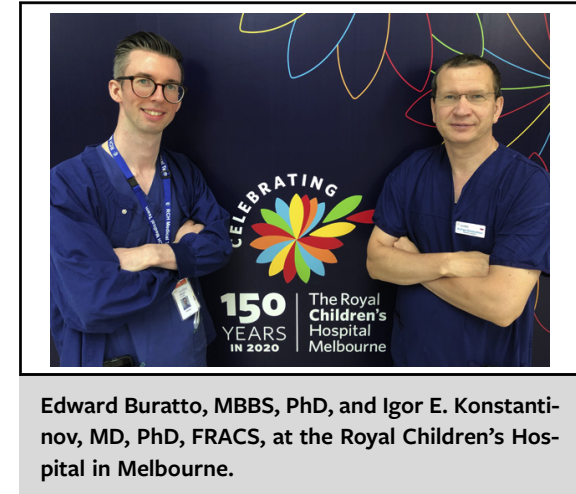

CENTRAL MESSAGE

Aortic aneurysms may occur in children and adults with congenital heart disease. An approach to surgical management of the aneurysm should be tailored to the underlying condition.

See Commentaries on pages 963 and 965 .

dissection. ${ }^{15,16}$ Subsequently, the simplified aortic diameter to height ratio was found to be predictive of dissection, rupture, and death. ${ }^{17}$ Although the Svensson's index has been shown to correlate well with aortic z-scores in children, ${ }^{18}$ it has not been validated for the prediction of dissection and rupture in children or adults with repaired congenital heart disease. When should we perform aortic root surgery in children without significant aortic insufficiency? Should we replace the aorta in children with an aneurysmal root when an adult-size graft can be placed? Should the aneurysmal aorta be replaced when it compresses adjacent structures even though the aortic size threshold has not been reached? What is the risk of aortic dissection or rupture in patients with repaired congenital heart disease? None of these important questions can be answered by the data derived from the current literature. Yet, with an ever-increasing population of children and adults with repaired congenital heart disease we will inevitably face these questions more often. In children, the largest study published to date described the outcomes of 100 patients, of whom $90 \%$ had connective tissue disorders, and provided institutional guidelines for aortic root replacement. ${ }^{2}$ At the present time, this study provides the best guidance on indications for aortic 
root surgery in children with connective tissue disorders and nonsyndromic congenital heart disease. ${ }^{2}$ Current surgical indications are summarized in Table 1.

\section{Patients With Connective Tissue Disorders}

Currently, surgery is recommended for asymptomatic children with connective tissue disorders (Figure 1, A) and a maximum aortic diameter greater than $5.0 \mathrm{~cm}$ in children with Marfan syndrome or greater than $4.5 \mathrm{~cm}$ in those with additional risk factors (family history dissection or rupture) or significant aortic valve insufficiency, whereas in children with Loeys-Dietz syndrome (LDS), the threshold of aortic root diameter is decreased to greater than $3.5 \mathrm{~cm}$ or an aortic Z-score greater than 3 . Rapid progression of the aortic root dilatation of greater than $0.5 \mathrm{~cm}$ per year appears to indicate aortic root surgery in any patient with connective tissue disorder. ${ }^{1-3}$

\section{Patients With Repaired Congenital Heart Defects}

There is now an ever-growing population of children and adults with repaired congenital heart disease who have an enlarged aortic root. It is not unusual to see patients after repair of conotruncal anomalies, particularly truncus arteriosus, tetralogy of Fallot, transposition of the great arteries (Figure 1, $B$ and $C$ ), with asymptomatic aortic root aneurysm. ${ }^{4}$ In patients without significant aortic valve insufficiency, indication for surgery is based on adult criteria, namely, maximal aortic root diameter greater than $5.5 \mathrm{~cm}$ in both bicuspid aortic valve and nonsyndromic aortic aneurysms. ${ }^{2}$

Neoaortic dilatation may also occur in patients who have undergone the Ross procedure (Figure 1, D). Autograft dilatation is more common in growing children. In older children and adults, the autograft root may be stabilized, thus reducing the rate of late dilatation. ${ }^{21,22}$ Furthermore, in the reoperative setting, the rate of autograft failure appears to be decreased, possibly due to postsurgical adhesions present after prior sternotomy that may provide an additional extrinsic support for the autograft. ${ }^{23}$ Attempts were made to predict autograft dilatation using proteomic technology. ${ }^{24}$ Although such prediction appears elusive at the present time, it may become useful with further technologic refinement in the future. ${ }^{25}$ Contemporary studies demonstrate that when the Ross operation is performed in childhood, the freedom from autograft reoperation is approximately $80 \%$ at 15 years, ${ }^{21}$ whereas when the Ross operation is performed in adults, the freedom from autograft failure is $96 \%$ at 15 years. ${ }^{22}$ Although described in a single case report, aortic dissection after the Ross procedure is exceptionally rare. ${ }^{26}$ Thus, autograft reoperation is mostly performed for aortic insufficiency. Rarely, aortic root replacement for autograft dilatation has been performed without aortic insufficiency for neoaortic root dilatation alone, based on autograft diameter greater than $5 \mathrm{~cm}$ or Svensson's index greater than 10 in adults. ${ }^{27,28}$ Does neoaortic root dilatation alone in children without significant

\begin{tabular}{|c|c|}
\hline $\begin{array}{lr}\text { TABLE } & \text { 1. Indications } \\
\text { summary }^{1-3,5,12,13,15,16,19,20}\end{array}$ & replacement \\
\hline Condition & Reported indications for surgery \\
\hline Marfan syndrome & $\begin{array}{l}\text { Diameter }>5.0 \mathrm{~cm} \\
\text { Growth }>0.5 \mathrm{~cm} / \mathrm{y} \\
\text { Svensson's index }>10 \\
\text { Diameter }>4.5 \mathrm{~cm} \text { if family history of AR } \\
\text { Diameter }>4.0 \mathrm{~cm} \text { if concomitant surgery } \\
\mathrm{Z} \text { score }>3-4\end{array}$ \\
\hline $\begin{array}{l}\text { Loeys-Dietz syndrome } \\
\text { All patients } \\
\text { Type I and II } \\
\text { Type III } \\
\text { Type IV }\end{array}$ & $\begin{array}{l}\text { Growth }>0.5 \mathrm{~cm} / \mathrm{y} \\
\text { Svensson's index }>10 \\
\text { Diameter }>3.5 \mathrm{~cm} \text { or } \mathrm{Z} \text { score } 3 \\
\text { Diameter }>4 \mathrm{~cm} \text { or } \mathrm{Z} \text { score }>4 \\
\text { Diameter }>4.5 \mathrm{~cm} \text { or } \mathrm{Z} \text { score }>4\end{array}$ \\
\hline Bicuspid valve & $\begin{array}{l}\text { Diameter }>5.5 \mathrm{~cm} \\
\text { Diameter }>4.5 \mathrm{~cm} \text { if concomitant surgery } \\
\text { Growth }>0.5 \mathrm{~cm} / \mathrm{y} \\
\text { Svensson's index }>10\end{array}$ \\
\hline Ross procedure & $\begin{array}{l}\text { Diameter }>5.0 \mathrm{~cm} \\
\text { Svensson's index }>10\end{array}$ \\
\hline $\begin{array}{l}\text { Nonsyndromic thoracic } \\
\text { aortic aneurysm }\end{array}$ & Diameter $>5.5 \mathrm{~cm}$ \\
\hline
\end{tabular}

aortic valve insufficiency after, for example, the Ross procedure or arterial switch operation warrant aortic root surgery? If so, then at what size? These questions are yet to be answered.

As the survival of children with univentricular physiology is improving, there is also a growing population with enlarged neoaortic roots (Figure 1,E) after univentricular palliation. Neoaortic root dilatation and insufficiency appear to progress over time..$^{29}$ The exact indication based on the aortic root diameter in these patients is even more obscure. Thus, aortic root surgery in patients with repaired congenital heart disease is typically performed for significant aortic, or neoaortic, valve insufficiency or compression of the adjacent structures by the aneurysm ${ }^{30}$ and the exceptionally rare event of dissection. ${ }^{7}$

\section{Surgical Techniques}

Valve-sparing surgical techniques that have been applied to aortic root dilatation are wrapping of the ascending aorta (Figure 2, $A$ ), replacement of aortic root using reimplantation (Figure 2, B), which appears to be the gold standard, or remodeling (Figure 2, C), replacement of the ascending aorta with root stabilization (Figure 2,D), or personalized external root support (PEARS) (Figure 2, E).

The earliest valve-sparing approach to the aortic root appears to be the wrapping technique described by Robicsek and colleagues, ${ }^{31}$ in which an aortoplasty is performed with elliptical excision and reapproximation of the ascending aortic wall. The ascending aorta is then wrapped with a vascular prosthesis, with small semicircles excised above the takeoff of the coronary arteries to avoid encroachment of the coronary orifices. ${ }^{11}$ 


\section{Congenital heart disease}

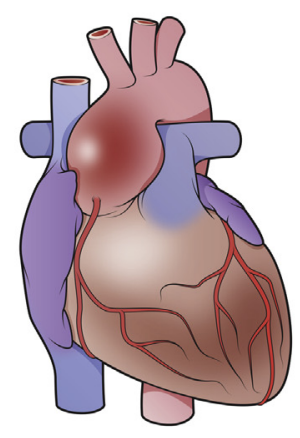

A

\begin{abstract}
Connective tissue
\end{abstract} disorders

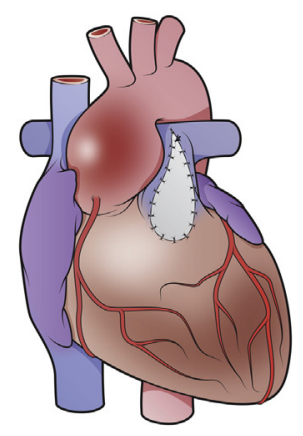

B $\begin{gathered}\text { Tetralogy of Fallot } \\ \text { repair }\end{gathered}$

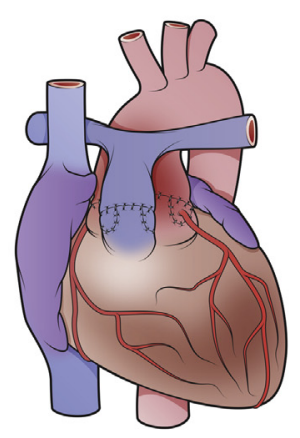

C Arterial switch

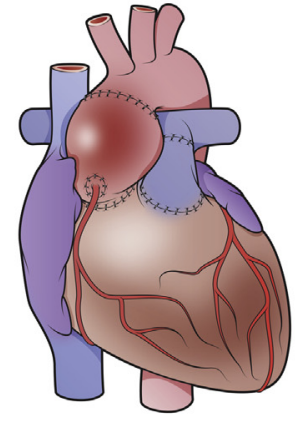

D

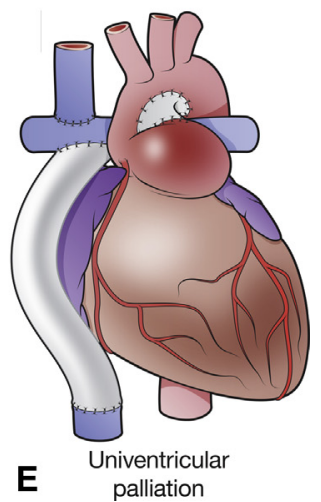

E Univentricula

FIGURE 1. Aortic root aneurysms in a spectrum of congenital heart disease.

In the current era, aortic root replacement has become the gold standard approach to valve-sparing aortic root surgery in both children and adults. There are 2 widely used techniques for valve-sparing root replacement: aortic root reimplantation (David procedure) and aortic root remodeling (Yacoub procedure). In the reimplantation technique, the aortic valve is sutured within an appropriately sized vascular graft, which supports the entire valve apparatus to a level bellow the nadir of each cusp. ${ }^{32,33}$ This technique can be used in patients with repaired congenital heart disease and has been reported in patients with univentricular palliation, ${ }^{15}$ prior arterial switch operation, ${ }^{34}$ and repaired tetralogy of Fallot in the setting of acute dissection. ${ }^{7}$ In the remodeling technique, a scalloped vascular graft is sutured to the rim of retained aortic wall on the aortic valve. ${ }^{35,36}$ In this technique, the aortic annulus is not supported within the graft. To avoid the risk of annular dilatation, an annuloplasty technique has been described using polytetrafluoroethylene suture (Gore-Tex CV-0; WL Gore and Associates, Newark, Del) ${ }^{36}$ or an aortic annuloplasty ring placed externally (Extra-Aortic; CORONEO Inc, Montreal, QC, Canada) ${ }^{19}$ or internally (BioStable Science and Engineering, Inc, Austin, Tex). ${ }^{20}$ Alternatively, the similar stabilization of the annulus can be achieved by circular strip of any synthetic material placed externally around the aortic annulus at the time of root remodeling.
More recently, newer techniques of external aortic root support have evolved from the concept originally described by Robicsek. ${ }^{16}$ The Florida sleeve technique involves placement of a vascular graft around the aortic root, with fenestrations, referred to as "keyholes," for the coronary arteries. The graft is secured at the annular level, externally supporting the aortic root, and the supracoronary aorta is replaced with a graft. ${ }^{8}$ The PEARS technique involves wrapping the aorta with a customized graft, which is secured, at the annular level, and is designed to be incorporated into the aortic wall. ${ }^{9,10}$ This procedure is unique in that it is an entirely extravascular prosthesis, which can be placed on the beating heart, and in most cases without the use of cardiopulmonary bypass. ${ }^{9,10}$

\section{RESULTS}

\section{Connective Tissue Disorders}

Fraser and colleagues ${ }^{2}$ reported the results of 100 patients, predominantly with Marfan syndrome $(51 \%)$ or LDS (39\%), who underwent valve-sparing root replacement from 1997 to 2017 at a median age of 13.6 years. The mean preoperative aortic sinus diameter was $4.4 \mathrm{~cm}$, and the mean z-score was 7.3. Most patients underwent reimplantation $(84 \%)$, with the remainder receiving remodeling $(13 \%)$ or the Florida sleeve $(3 \%)$. Early mortality was $2 \%$, and 10 -year survival was $88 \%$.

\section{Valve-sparing aortic root surgery}

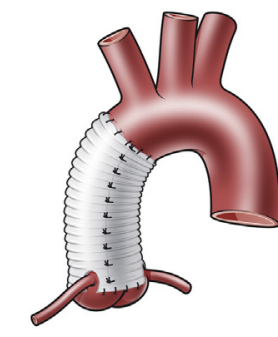

A Robicsek wrap
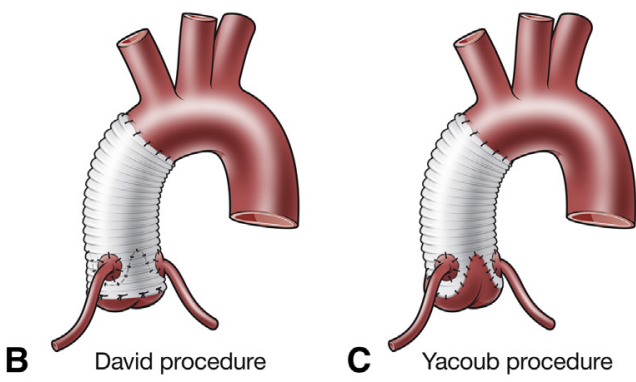

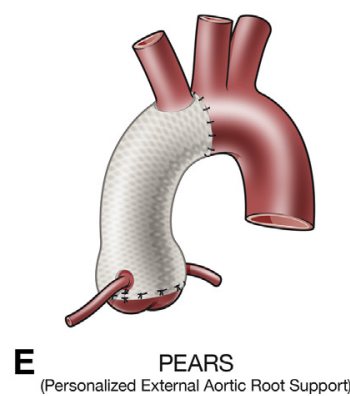

FIGURE 2. Types of valve-sparing aortic root surgeries in congenital heart disease. 
Freedom from reintervention was $70 \%$ at 10 years, and the risk of reoperation for aortic valve replacement was significantly higher with remodeling than reimplantation $(31 \%$ vs $5 \%, P=.001)$. Furthermore, they abandoned the use of the Florida sleeve procedure, because all 3 patients who underwent this technique required reoperation with the reimplantation technique.

Patel and colleagues ${ }^{37}$ reported 31 patients with LDS who underwent valve-sparing root replacement between 1992 and 2015 at a mean age of 10 years. In most cases, they used the reimplantation technique $(27 / 31,87.1 \%)$ followed by the Florida sleeve $(3 / 31,9.7 \%)$ and the remodeling technique $(1 / 31,3.2 \%)$. The mean preoperative aortic sinus diameter was $4.0 \mathrm{~cm}$, and the mean $\mathrm{z}$-score was 7.8 . There were no early deaths, and survival at 10 years was $95 \%$. Freedom from reintervention on the aorta was $54 \%$ at 10 years.

Kluin and colleagues ${ }^{38}$ reported 19 patients, predominantly with Marfan syndrome, who underwent valve-sparing root replacement between 2003 and 2015 at a median age of 13.2 years. The mean preoperative aortic sinus diameter was $4.4 \mathrm{~cm}$, and the mean z-score was 4.9 . There were no early deaths and a single late death $(5.3 \%)$ with a mean follow-up of 4.4 years. Freedom from greater than mild AR was $85 \%$ at 10 years.

Roubertie and colleagues ${ }^{39}$ reported 11 patients, predominantly with Marfan syndrome, who underwent valve-sparing root replacement with the remodeling technique between 1986 and 2007 at a mean age of 10 years. The mean aortic sinus diameter was $4.7 \mathrm{~cm}$, with a mean z-score not reported. There was 1 early death $(9.1 \%)$, and freedom from reoperation at 5 years was $46 \%$. They cautioned against the use of the remodeling technique in children because of the high reoperation rate.

Rakhra and colleagues ${ }^{40}$ reported 10 patients who underwent valve-sparing aortic root replacement from 2002 to 2011 at a median age of 15 years. The mean aortic sinus diameter was $4.8 \mathrm{~cm}$, with a mean z-score of 5.9. There were no operative or late deaths at a median follow-up of 4.1 years. Redo aortic root surgery was required in 1 patient for AR and 1 patient for infective endocarditis.

Aalaei-Andabili and colleagues ${ }^{41}$ reported 37 patients with Marfan syndrome who underwent the Florida sleeve procedure between 2002 and 2014 at a mean age of 37 years. The mean aortic root diameter was $4.9 \mathrm{~cm}$. There were no operative deaths. Survival and freedom from reoperation at 8 years were $95 \%$ and $100 \%$, respectively.

Treasure and colleagues ${ }^{9}$ reported the results of 30 children and young adults who underwent PEARS between 2004 and 2011 at a median age of 28 years. The mean aortic diameter was $4.6 \mathrm{~cm}$ preoperatively. There were no early or late deaths and no reoperations at a mean follow-up of 4.4 years. Izgi and colleagues ${ }^{10}$ reported 24 patients preoperative and postoperative magnetic resonance imaging who underwent PEARS for aortic root dilatation with a diagnosis of Marfan syndrome between 2004 and 2012 at a mean age of 33 years. The mean preoperative diameter of the sinus of Valsalva was $4.5 \mathrm{~cm}$. They demonstrated that at a mean follow-up of 6.3 years, the PEARS graft could stabilize the aortic root and ascending aorta, with no change in diameter over that period. However, it should be noted that as yet only small series of PEARS root stabilizations have been published, and results have not been reported in children.

\section{Patients With Repaired Congenital Heart Defects}

Myers and colleagues ${ }^{5}$ reported 29 patients who underwent valve-sparing root surgery between 2000 and 2012 at a mean age of 15 years with $62 \%(18 / 29)$ having congenital heart disease. They used aortic root remodeling in 55\% $(16 / 29)$ and reimplantation in $45 \%$ (13/29) of patients. The mean aortic root diameter and z-score were $4.1 \mathrm{~cm}$ and 6.5 for reimplantation, and $3.7 \mathrm{~cm}$ and 5.9 for remodeling, respectively. There were no operative deaths. Freedom from structural valve degeneration was $70 \%$ at 1 year. They found that the reimplantation technique and the use of a smaller graft to native annulus ratio were associated with increased risk of valve failure. They suggested that undersizing of the graft in the reimplantation technique could have resulted in earlier structural valve deterioration.

Stulak and colleagues ${ }^{4}$ reported 81 patients with a dilated ascending aorta after prior repair of conotruncal anomalies who underwent reoperation on the aortic root $(9 \%, 7 / 81)$, aortic valve replacement $76 \%(62 / 81)$, aortic valve repair $(12 \%, 10 / 81)$, or isolated ascending aorta replacement $(2.5 \%, 2 / 81)$ between 1973 and 2008. The mean aortic diameter was $45 \mathrm{~mm}$, but only $9 \%$ (7/81) underwent aortic root replacement. Although the aortic root was not replaced in most patients, the 10-year freedom from subsequent reoperation on the aorta was $100 \%$. They concluded that moderate aortic dilatation in patients with conotruncal anomalies is common, but because dissection is rare, the moderately dilated aorta in this setting may be observed.

\section{CONCLUSIONS}

Aortic root stabilization in children and adults with congenital heart disease may be achieved by replacing or externally supporting the aortic root. Aortic root replacement with the reimplantation technique appears to provide better freedom from reoperation compared with the remodeling technique. Techniques of external support demonstrate similar results to root replacement in adults, but there has been limited experience in children so far. The indications for both aortic root surgery per se and the type of aortic root surgery in children and adults with congenital heart disease are yet to be refined.

\section{Conflict of Interest Statement}

The authors reported no conflicts of interest. 
The Journal policy requires editors and reviewers to disclose conflicts of interest and to decline handling or reviewing manuscripts for which they may have a conflict of interest. The editors and reviewers of this article have no conflicts of interest.

\section{References}

1. Vricella LA, Cameron DE. Valve-sparing aortic root replacement in pediatric patients: lessons learned over two decades. Semin Thorac Cardiovasc Surg Pediatr Card Surg Annu. 2017;20:56-62.

2. Fraser CD III, Liu RH, Zhou X, Patel ND, Lui C, Pierre AS, et al. Valve-sparing aortic root replacement in children: outcomes from 100 consecutive cases. $J$ Thorac Cardiovasc Surg. 2019;157:1100-9.

3. Zanotti G, Vricella L, Cameron D. Thoracic aortic aneurysm syndrome in children. Semin Thorac Cardiovasc Surg Pediatr Card Surg Annu. 2008;11:11-21.

4. Stulak JM, Dearani JA, Burkhart HM, Sundt TM, Connolly HM, Schaff HV. Does the dilated ascending aorta in an adult with congenital heart disease require intervention? J Thorac Cardiovasc Surg. 2010;140(6 Suppl):S52-91.

5. Myers PO, del Nido PJ, Emani SM, Marx GR, Baird CW. Valve-sparing aortic root replacement and remodeling with complex aortic valve reconstruction in children and young adults with moderate or severe aortic regurgitation. J Thorac Cardiovasc Surg. 2014;147:1768-74.

6. Zalzstein E, Hamilton R, Zucker N, Diamant S, Webb G. Aortic dissection in children and young adults: diagnosis, patients at risk, and outcomes. Cardiol Young. 2003;13:341-4.

7. Konstantinov IE, Fricke TA, d'Udekem Y, Robertson T. Aortic dissection and rupture in adolescents after tetralogy of Fallot repair. J Thorac Cardiovasc Surg. 2010;140:e71-3.

8. Hess PJ Jr, Klodell CT, Beaver TM, Martin TD. The Florida sleeve: a new technique for aortic root remodeling with preservation of the aortic valve and sinuses. Ann Thorac Surg. 2005;80:748-50.

9. Treasure T, Takkenberg JJ, Golesworthy T, Rega F, Petrou M, Rosendahl U, et al. Personalised external aortic root support (PEARS) in Marfan syndrome: analysis of 1-9 year outcomes by intention-to-treat in a cohort of the first 30 consecutive patients to receive a novel tissue and valve-conserving procedure, compared with the published results of aortic root replacement. Heart. 2014;100:969-75.

10. Izgi C, Newsome S, Alpendurada F, Nyktari E, Boutsikou M, Pepper J, et al. External aortic root support to prevent aortic dilatation in patients with Marfan syndrome. J Am Coll Cardiol. 2018;72:1095-105.

11. Robicsek F, Cook JW, Reames MK Sr, Skipper ER. Size reduction ascending aortoplasty: is it dead or alive? J Thorac Cardiovasc Surg. 2004;128:562-70.

12. Hiratzka LF, Bakris GL, Beckman JA, Bersin RM, Carr VF, Casey DE Jr, et al. 2010 ACCF/AHA/AATS/ACR/ASA/SCA/SCAI/SIR/STS/SVM guidelines for the diagnosis and management of patients with thoracic aortic disease: a report of the American College of Cardiology Foundation/American Heart Association task force on practice guidelines, American Association for Thoracic Surgery, American College of Radiology, American Stroke Association, Society of Cardiovascular Anesthesiologists, Society for Cardiovascular Angiography and Interventions, Society of Interventional Radiology, Society of Thoracic Surgeons, and Society for Vascular Medicine. Circulation. 2010;121:e266-369.

13. Borger MA, Fedak PWM, Stephens EH, Gleason TG, Girdauskas E, Ikonomidis JS, et al. The American Association for Thoracic Surgery consensus guidelines on bicuspid aortic valve-related aortopathy: Full online-only version. J Thorac Cardiovasc Surg. 2018;156:e41-74.

14. Clark JB. Continued pursuit of evidence-based indications and the optimal operation for pediatric valve-sparing aortic root replacement. J Thorac Cardiovasc Surg. October 12, 2018 [Epub ahead of print].

15. Svensson LG, Khitin L. Aortic cross-sectional area/height ratio timing of aortic surgery in asymptomatic patients with Marfan syndrome. J Thorac Cardiovasc Surg. 2002; 123:360-1.

16. Svensson LG, Kim KH, Lytle BW, Cosgrove DM. Relationship of aortic crosssectional area to height ratio and the risk of aortic dissection in patients with bicuspid aortic valves. J Thorac Cardiovasc Surg. 2003;126:892-3.

17. Zafar MA, Li Y, Rizzo JA, Charilaou P, Saeyeldin A, Velasquez CA, et al. Height alone, rather than body surface area, suffices for risk estimation in ascending aortic aneurysm. J Thorac Cardiovasc Surg. 2018;155:1938-50.

18. Mariucci E, Donti A, Guidarini M, Oppido G, Angeli E, Lovato L, et al. Diagnostic accuracy of aortic root cross-sectional area/height ratio in children and young adults with Marfan and Loeys-Dietz syndrome. Congenit Heart Dis. 2016;11:276-82.
19. Lansac E, Di Centa I, Sleilaty G, Lejeune S, Berrebi A, Zacek P, et al. Remodeling root repair with an external aortic ring annuloplasty. J Thorac Cardiovasc Surg. 2017; 153:1033-42.

20. Mazzitelli D, Nöbauer C, Rankin JS, Badiu CC, Dorfmeister M, Crooke PS, et al Early results of a novel technique for ring-reinforced aortic valve and root restoration. Eur J Cardiothorac Surg. 2014;45:426-30.

21. Donald JS, Wallace FRO, Naimo PS, Fricke TA, Brink J, Brizard CP, et al. Ross operation in children: 23-year experience from a single institution. Ann Thorac Surg. 2020;109:1251-9.

22. Skillington PD, Mokhles MM, Takkenberg JJ, Larobina M, O'Keefe M, Wynne R, et al. The Ross procedure using autologous support of the pulmonary autograft: techniques and late results. J Thorac Cardiovasc Surg. 2015;149:S46-52.

23. Buratto E, Wallace FRO, Fricke TA, Brink J, d'Udekem Y, Brizard CP, et al. Ross procedures in children with previous aortic valve surgery. J Am Coll Cardiol. 2020;76:1564-74.

24. Chiarini A, Dal Prà I, Faggian G, Armato U, Luciani GB. Maladaptive remodeling of pulmonary artery root autografts after Ross procedure: a proteomic study. $J$ Thorac Cardiovasc Surg. 2020;159:621-34.

25. Konstantinov IE, Caldaroni F, Ivanov Y. Commentary: prediction of pulmonary root dilatation after Ross operation-The power of protein shake? J Thorac Cardiovasc Surg. 2020;159:635-6.

26. Richey S, Fiore AC, Huddleston CB. Type A aortic dissection after the Ross procedure. Ann Thorac Surg. 2018;106:e105-6.

27. Ratschiller T, Eva SD, Schimetta W, Paulus P, Müller H, Zierer A, et al. Valvesparing root replacement for freestanding pulmonary autograft aneurysm after the Ross procedure. J Thorac Cardiovasc Surg. 2018;155:2390-7.

28. Luciani GB, Lucchese G, De Rita F, Puppini G, Faggian G, Mazzucco A. Reparative surgery of the pulmonary autograft: experience with Ross reoperations. Eur $J$ Cardiothorac Surg. 2012;41:1309-15.

29. Cohen MS, Marino BS, McElhinney DB, Robbers-Visser D, van der Woerd W, Gaynor JW, et al. Neo-aortic root dilation and valve regurgitation up to 21 years after staged reconstruction for hypoplastic left heart syndrome. J Am Coll Cardiol. 2003;42:533-40.

30. Pizarro C. Valve sparing neo-aortic root replacement post Norwood. Oper Tech Thorac Cardiovasc Surg. 2019;25:2-12.

31. Robicsek F, Daugherty K, Mullen DC, Harbold NB Jr, Masters TN. Is there a place for wall reinforcement in modern aortic surgery? Arch Surg. 1972;105: $827-9$.

32. David TE, Feindel CM. An aortic valve-sparing operation for patients with aortic incompetence and aneurysm of the ascending aorta. J Thorac Cardiovasc Surg. 1992;103:617-22.

33. David TE, David CM, Feindel CM, Manlhiot C. Reimplantation of the aortic valve at 20 years. J Thorac Cardiovasc Surg. 2017;153:232-8.

34. Gomibuchi T, Okada K, Seto T, Okita Y. Valve-sparing aortic root replacement after double-switch operation for corrected transposition of the great arteries in a patient with ulcerative colitis. J Thorac Cardiovasc Surg. 2018; 155:e175-6.

35. Sarsam MA, Yacoub M. Remodeling of the aortic valve annulus. J Thorac Cardiovasc Surg. 1993;105:435-8.

36. Schneider U, Schafers HJ. Aortic root remodelling. Oper Tech Thorac Cardiovasc Surg. 2018;3:102-20.

37. Patel ND, Alejo D, Crawford T, Hibino N, Dietz HC, Cameron DE, et al. Aortic root replacement for children with Loeys-Dietz syndrome. Ann Thorac Surg. 2017; 103:1513-8.

38. Kluin J, Koolbergen DR, Sojak V, Hazekamp MG. Valve-sparing root replacement in children. Eur J Cardiothorac Surg. 2016;50:476-81.

39. Roubertie F, Ben Ali W, Raisky O, Tamisier D, Sidi D, Vouhé PR. Aortic root replacement in children: a word of caution about valve-sparing procedures. Eur J Cardiothorac Surg. 2009;35:136-40.

40. Rakhra SS, Brizard CP, d'Udekem Y, Konstantinov IE. Valve-sparing aortic root replacement in children. J Thorac Cardiovasc Surg. 2012;144: 980-1.

41. Aalaei-Andabili SH, Martin T, Hess P, Klodell C, Karimi A, Arnaoutakis G, et al Florida sleeve procedure is durable and improves aortic valve function in Marfan syndrome patients. Ann Thorac Surg. 2017;104:834-9.

Key Words: aortic root aneurysm, autograft, connective tissue disorders, conotruncal anomalies, neoaortic root, Ross operation, valve-sparing aortic root replacement 


\section{Valve-sparing aortic root surgery in children: Recent Articles from AATS Journals}
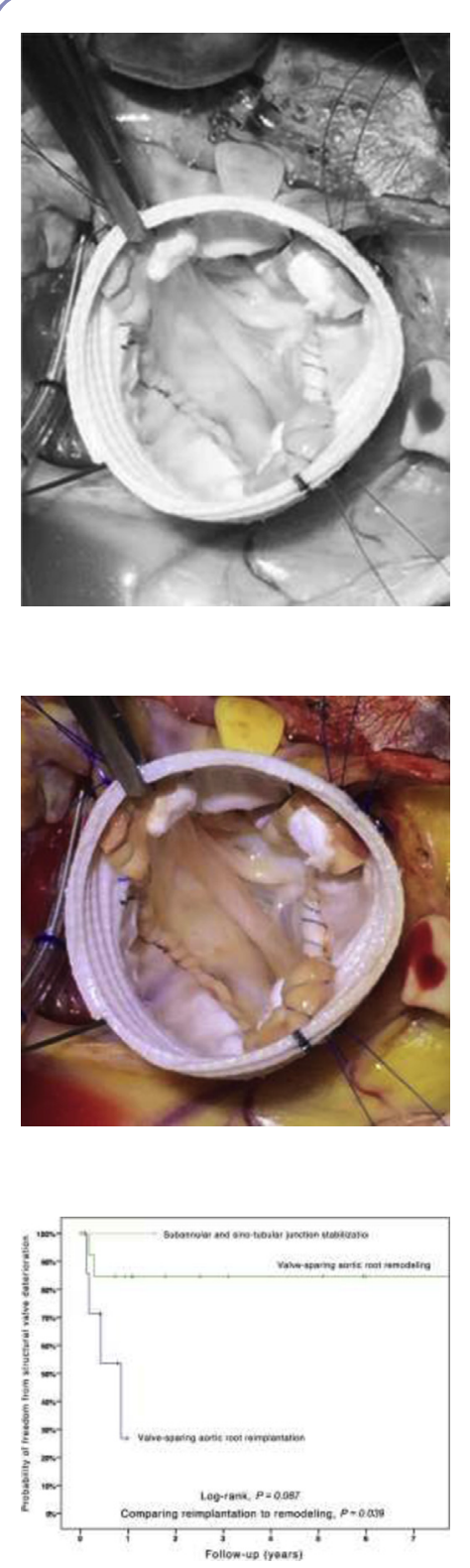

PED ANN: Valve-sparing aortic root replacement in pediatric patients: Lessons learned over two decades. Vricella LA, Cameron DE. Semin Thorac Cardiovasc Surg Pediatr Card Surg Annu. 2017;20:56-62.

JTCVS: Valve-sparing aortic root replacement in children: Outcomes from 100 consecutive cases. Fraser CD $3^{\text {rd }}$, Liu RH, Zhou X, Patel ND, Lui C, Pierre AS, Jacobs ML, Dietz HC, Habashi J, Hibino N, Cameron DE, Vricella LA. J Thorac Cardiovasc Surg. 2019;157(3): 1100-1109.

Commentary: Pediatric valve-sparing aortic root replacement: Approaching perfection. Burkhart HM, Thompson JL, Campbell M. J Thorac Cardiovasc Surg. 2019;157(3):1110-1111. Commentary: Continued pursuit of evidence-based indications and the optimal operation for pediatric valve-sparing aortic root replacement. Clark JB. Thorac Cardiovasc Surg. 2019; 157(3):1112-1113.

JTCVS: Valve-sparing aortic root replacement and remodelling with complex aortic valve reconstruction in children and young adults with moderate or severe aortic regurgitation. Myers PO, del Nido PJ, Emani SM, Marx GR, Baird CW. J Thorac Cardiovasc Surg. 2014;147(6):1768-1776. 


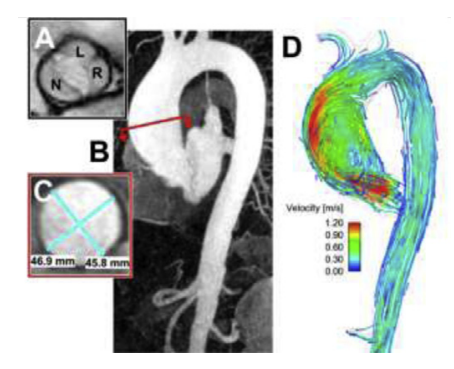

JTCVS: The American Association for Thoracic Surgery consensus guidelines on bicuspid aortic valve-related aortopathy: Full online-only version. Borger MA, Fedak PWM, Stephens EH, Gleason TG, Girdauskas E, Ikonomidis JS, Khoynezhad A, Siu SC, Verma S, Hope MD, Cameron DE, Hammer DF, Coselli JS, Moon MR, Sundt TM, Barker AJ, Markl M, Corte AD, Michelena HI, Elefteriades JA. J Thorac Cardiovasc Surg. 2018;156(2) E41-E74.

Commentary: Everybody is different: A plea for individualizing treatment of aortopathy. Sievers HH. J Thorac Cardiovasc Surg. 2018;156(2):481-482.

Commentary: Bicuspid aortic valve with aortic aneurysms. David TE. J Thorac Cardiovasc Surg. 2018;156(2):467-468.

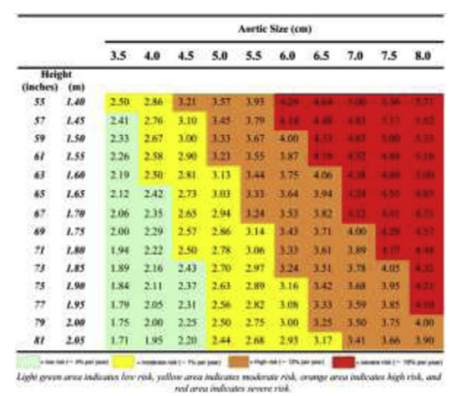

JTCVS: Height alone, rather than body surface area, suffices for risk estimation in ascending aortic aneurysm. Zafar MA, Li Y, Rizzo JA, Charilaou P, Saeyeldin A, Velasquez CA, Mansour AM, Mahmood SUB, Ma WG, Brownstein AJ, Tranquilli M, Dumfarth J, Theodoropoulos P, Thombre K, Tanweer M, Erben Y, Peterss S, Ziganshin BA, Elefteriades JA. J Thorac Cardiovasc Surg. 2018;155(5):1938-1950.

Commentary: Does being overweight reduce accuracy in predicting an acute aortic dissection? De Paulis R. J Thorac Cardiovasc Surg. 2018;155(5):1951-1952.

Commentary: Height supersedes weight: Height-diameter indexing keeps you ahead of the game. Czerny M. J Thorac Cardiovasc Surg. 2018;155(5):1925.

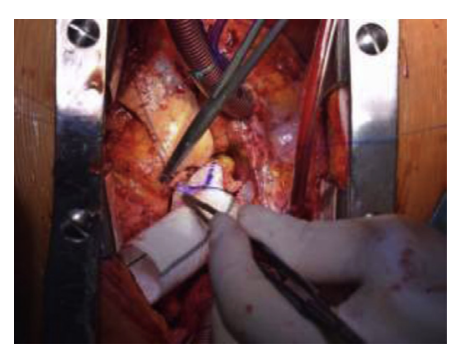

JTCVS: Valve-sparing root replacement for freestanding pulmonary autograft aneurysm after the Ross procedure. Ratschiller T, Eva SD, Schimetta W, Paulus P, Müller H, Zierer A, Mair R. J Thorac Cardiovasc Surg. 2018;155(6):2390-2397.

Commentary: Expanding the results of the Ross operation. Mastrobuoni S, El Khoury G. J Thorac Cardiovasc Surg. 2018;155(6):2398-2399.

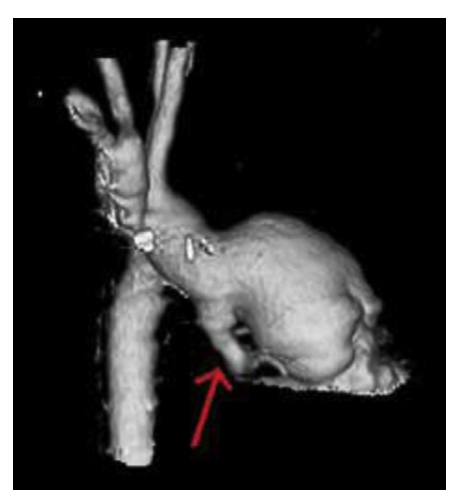

JTCVS: Valve-sparing neo-aortic root replacement after Fontan completion for hypoplastic left heart syndrome. Pizarro C, Baffa JM, Derby CD, Krieger PA. J Thorac Cardiovasc Surg. 2011;141(4):1083-1084. 


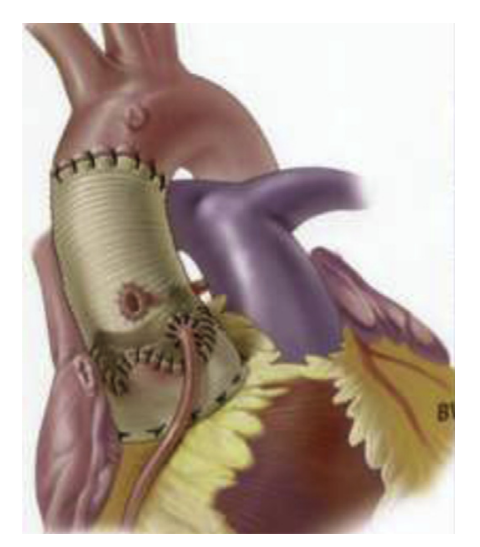

JTCVS: Reimplantation of the aortic valve at 20 years. David TE, David CM, Feindel CM, Manlhiot C. J Thorac Cardiovasc Surg. 2017;153(2):232-238.

Commentary: To pleat or not to pleat. .. is that the question? Gleason TG. J Thorac Cardiovasc Surg. 2017;153(2):239-240.

Commentary: Valve-sparing aortic root replacement: Surgeon and patient factors contribute to long-term durability. Ikonomidis JS. J Thorac Cardiovasc Surg. 2017;153(2):230-231.

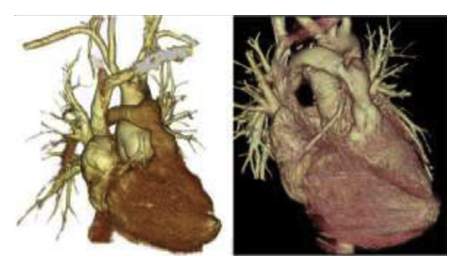

JTCVS: Valve-sparing aortic root replacement after double-switch operation for corrected transposition of the great arteries in a patient with ulcerative colitis. Gomibuchi T, Okada K, Seto T, Okita Y. J Thorac Cardiovasc Surg. 2018;155(6):E175-E176. Commentary: Valve-sparing root surgery in congenital heart disease-Shoulda, coulda... Dearani JA. J Thorac Cardiovasc Surg. 2018;155(6):E177-E178.

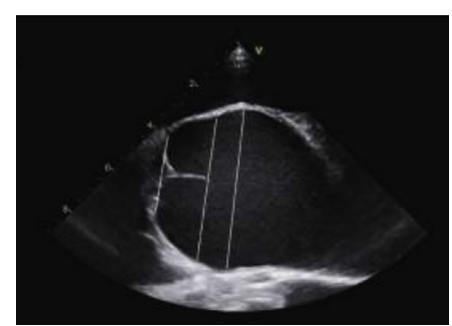

OP TECHS: Aortic root remodelling. Schneider U, Schäfers HJ. Oper Tech Thorac Cardiovasc Surg. 2018;23(3):102-120.

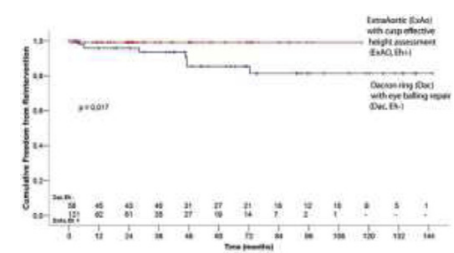

JTCVS: Remodeling root repair with an external aortic ring annuloplasty. Lansac E, Di Centa I, Sleilaty G, Lejeune S, Berrebi A, Zacek P, Debauchez M. J Thorac Cardiovasc Surg. 2017;153(5):1033-1042.

Commentary: Aortic annuloplasty: The panacea of valve-preserving aortic replacement? Schäfers HJ. J Thorac Cardiovasc Surg. 2017;153(5):1043-1044. 